\title{
A szülői-pedagógusi attitűd és a tanulói önértékelés, személyiségfejlődés összefüggéseinek vizsgálata szakgimnáziumi és szakközépiskolai tanulók körében
}

\section{Bevezetés}

Napjainkban egyre fontosabb, hogy egy mai modern, korszerű iskolarendszer törekedjen arra, hogy megfeleljen az éppen aktuális társadalmi-gazdasági követelményeknek, elvárásoknak. Ezek az elvárások ma már nemcsak szakmai jellegúek, talán még fontosabb, hogy a munkavállaló mennyire magabiztos, hogyan gondolkodik a világról, mennyire fejlett az érzelmi intelligenciája, tud-e csapatban dolgozni, kellőképpen igényes-e önmagára és a munkájára. A szakmai hiányosságok tanulással és tapasztalattal könnyedén pótolhatók, az érzelmi intelligencia hiánya és a negatív énkép csak nagyon nehezen orvosolható, ha orvosolható egyáltalán. Ezért rendkívül fontos, hogy otthonról, illetve az oktatási intézményekből milyen lelki munícióval érkezik a fiatal a munka világába. A jelenkori demográfiai hullámvölgynek köszönhetően az intézményvezetők igen nagy kihívásokkal néznek szembe, egyre nagyobb gondot jelent a csökkenő tanulólétszám, így egyre hangsúlyosabb szerepet kap, mennyire rátermett az intézmény vezetője, akinek egyszerre többféle területen kell helytállnia, hogy az általa vezetett iskola talpon maradhasson, illetve megfeleljen a fent említett társadalmigazdasági elvárásoknak. Alkalmasnak kell lennie arra, hogy megfelelő gazdálkodással, érdekes, innovatív programokkal, tudatosan felépített és irányított marketinggel (szakgimnáziumok, szakközépiskolák esetében széleskörű és piacképes szakmakínálattal) valamint magas szintű oktatónevelő munkával csalogassa a diákokat az intézménybe. Ez utóbbi részben úgy érhető el, hogy olyan pedagógusokat alkalmaz vagy nevel ki az adott intézményvezető, akik mind tudásukkal, mind magatartásukkal, mind professzionális munkájukkal képesek hozzájárulni a tanulók intellektuális és erkölcsi fejlődéséhez, ezzel segítve őket hozzá ahhoz, hogy később a társadalom hasznos, értékes tagjaivá válhassanak. Úgy gondolom, hogy egy iskola értékét valójában az mutatja meg leginkább, hogy az általa kibocsátott fiatalok hogyan állják meg helyüket az életben, nyilván különböző iskolatípusok különböző pályákra készítenek fel, de a siker kulcsa ettől független.

Jelen vizsgálatom legfőbb célja az volt, hogy megismerjem a szülői-nevelői illetve a pedagógusi attitűdöket, valamint egy panelvizsgálat segítségével megkeressem az összefüggést a megismert attitűdök és a tanulói önértékelés között. Mivel a gyermek egészen a felnőttkor eléréséig a szülők és a pedagógusok (mint felnőtt minta) befolyása alatt fejlődik és nevelődik, nyilvánvaló, hogy e két tényező döntően formálja a tanuló önmagáról alkotott képét. Emellett fontos tényező még a kortárscsoportok befolyása is, de jelen dolgozatomnak ez utóbbi nem témája. Ennek az ún. panelvizsgálatnak a segítségével 30 szakgimnáziumi és 30 szakközépiskolai diákot kérdeztem meg három különböző témáról. E három téma a következő: a vizsgált tanuló önértékelése, a vizsgált tanuló tapasztalata saját szüleinek nevelői attitúdjéről, valamint a vizsgált tanuló élménye az általa leggyakrabban tapasztalt pedagógusi attitűdökről. Ezután a felmérés kiértékelését követően igyekeztem az összefüggéseket feltárni a szülői valamint pedagógusi attitűdök és a tanuló önértékelése között. A vizsgálat elvégzését megelőzően azt reméltem, hogy mérhető bizonyítékot kapok arra vonatkozóan, mely szülői illetve mely pedagógusi attitűdök befolyásolják kedvezően, és melyek befolyásolják negatívan a tanulók önértékelését. Ha ez valóban mérhető, akkor pedagógusként (a szülői attitűdök megismerésének köszönhetően) célzottabb nevelési módszereket alkalmazhatunk a tanulók motiválása, egészséges 
énképének kialakítása érdekében, valamint intézményvezetőként (a pedagógusi attitűdök vizsgálatával) információkat gyűjthetünk arról, mely életkorban mely pedagógusi attitúdök hatnak leginkább pozitívan a tanulói önértékelésre, ezáltal segítségül szolgálhat a lehető leghatékonyabb tanári kar megszervezésében, illetve a pedagógusok munkájának orientálásában.

\section{Az attitűd fogalma, dimenziói, funkciói}

A szociálpszichológia egyik közkedvelt fogalma, az attitüd, az olasz attitudine szóból származik, melynek jelentése: adott feladatok hatékony elvégzéséhez szükséges képesség. ${ }^{1}$ Szociálpszichológiai értelemben az 1960-as évek vége óta említik a szakirodalmak, „az első tudományos ismertetések Hunyady György tollából születtek". ${ }^{2}$ Az attitúdök tulajdonképpen pozitív vagy negatív viszonyulások személyek, tárgyak, csoportok, politikai nézetek vagy bármilyen más tárgy, fogalom vagy ideológia iránt, melyeket gyakran egy egyszerű véleményként fogalmazunk meg, mely lehet érzésekre alapuló: „szeretem a jógát”, vagy ismeretekre, vélekedésekre épülő: „a jóga az egyik legjobb alak- és lélekformáló tevékenység.", de lehet cselekedetekhez kapcsolódó is: „minden este jógázok.”. A szociálpszichológia ennek okán tehát az attitúdöket kognitív, affektív és viselkedéses összetevők együtteseként fogja fel.

„Az attitűd alapvető dimenziója az érzelmi-értékelési tartomány." ${ }^{3}$ Egy adott attitűdtárgy pozitív vagy negatív irányba lendítheti az emberek hozzá kapcsolódó attitűdjeit. Ha egy embernek pozitív az attitűdje a szóban forgó attitúdtárgy iránt, akkor az azt jelenti, hogy előnyben részesíti, kedveli, szereti, imádja, rajong érte, azonban ha negatív az attitúdje, akkor hátrányosan megkülönbözteti, mellőzi, rosszalja, gyúlöli, vagy akár undorodik tőle. Az attitűdöket vizsgáló szakembereknek tehát egyik fő feladata az, hogy az attitűdök irányát, érzelmi pólusok közötti helyzetét felmérje. Másik feladata „, $a z$ attitüd elhelyezkedésének megállapítása a pozitív és negatív pólus között feszülö tartományban”. ${ }^{4}$ Értelemszerúen minél közelebb helyezkedik el egyik vagy másik pólushoz, annál jobban szereti vagy gyűlöli a vizsgált személy az adott attitúdtárgyat. Fontos attitúddimenzió a relevancia is, mely tulajdonképpen „az attitüd személyiségbe való beágyazottságának mértéke, a hit, a meggyőződés, az elhivatottság jegye" ${ }^{5}$ Nem mindegy tehát, hogy az attitűdtárggyal kapcsolatos negatív vagy pozitív érzésem csak egyszerű vélemény, vagy komoly, elhivatott meggyőződés.

D. Katz az attitűdök szerepét az ember életében négy fő funkcióban jelölte meg (Katz, 1979). Az első az énvédő funkció, vagyis az önvédelem, az értékkifejező funkció, mely annál nyilvánvalóbban jelentkezik, minél relevánsabb egy adott attitúd. A harmadik az eszköz funkció, mely a társadalmi környezethez való alkalmazkodást jelöli meg. Az utolsó, azaz a negyedik, a megismerési, ismereti vagy másnéven tudásfunkció talán a legfontosabb a négy közül, „melynek révén az egyén szabályozottnak, értelmesnek és helyénvalónak érzi s tudja viselkedését, az őt körülvevő társadalmi világot"6. Valójában az attitűdök tanulmányozásának egyik fő oka, hogy minél pontosabban feltérképezhessék, lehetővé tegyék a viselkedés bejóslását. Az attitűdök jobban bejósolják a viselkedést, ha erősek, konzisztensek, ha a személy közvetlen tapasztalatán alapulnak vagy specifikusan kapcsolódnak az előre jelzett

\footnotetext{
1 Pszichológiai alapfogalmak kis enciklopédiája, Tankönyvkiadó, Budapest, 1987, 29. p.

2 Csepeli György, Szociálpszichológia, Osiris Kiadó, Budapest, 2001, 220. p.

${ }^{3}$ Csepeli György, Szociálpszichológia, Osiris Kiadó, Budapest, 2001, 224. p.

${ }^{4}$ Csepeli György, Szociálpszichológia, Osiris Kiadó, Budapest, 2001, 224. p.

${ }^{5}$ Csepeli György, Szociálpszichológia, Osiris Kiadó, Budapest, 2001, 224. p.

${ }^{6}$ Csepeli György, Szociálpszichológia, Osiris Kiadó, Budapest, 2001, 226. p.
} 
viselkedéshez. ${ }^{7}$ Tehát ami a legtöbb szakembert foglalkoztatja a fogalommal kapcsolatban, az a vélekedések, az érzések és a viselkedés közti kapcsolat.

\section{A család mint szocializációs környezet, a szülői-nevelői attitúdök}

A család az emberiség egyik legősibb intézménye. A különböző kultúrákban különféle elképzelés és szokásrend alakult ki a család meghatározását illetően, azonban egy biztos, hogy a világ minden táján ez az életkeret az, amely a legkorábbi életszakasztól kezdve hat a fejlődő egyénre: melyben biológiai létünk megvalósul, pszichés fejlődésünk alapvető jegyeit, individuális arculatát bontja ki. ${ }^{8} \mathrm{~A}$ család szocializációs funkciója több síkon érvényesül: a gyermek fejlődésére értelemszerűen nemcsak a nyilvánvaló, hangoztatott nevelési módszerek (pl. tiltás, jutalmazás, fegyelmezés, tanítás, ellenőrzés... stb.) hatnak, hanem a mélyben lapuló, kimondatlan, sokszor tudattalan magatartásformák, szerepminták is. Az elsődleges (primer), szándéktalanul érvényesülő családi ráhatás, azaz szociális tanulás az együttélés során folyamatos, mindennapos benyomás a fejlődő lélek számára, melynek kimutathatóan erőteljes hatása van viselkedésére, emberi kapcsolataira. A másodlagos, tudatosan irányított nevelésnek elsősorban a gyermek magatartásának, értékrendjének, életprogramjának kialakításában van fontos szerepe. ${ }^{9}$ A szülők modellhatása tehát az egyik legerősebb szocializáló erő, mely részben észrevétlenül érvényesül.

A szülői-nevelői attitűdök, illetve azoknak a gyermek lelki fejlődésére való hatásának vizsgálata, megismerése fontos lehet, miközben azt szeretnénk feltérképezni, hogy egy gyermeknek, adott esetben tanulónak a szorongása vagy agressziója milyen okokra vezethető vissza. Dr. Ranschburg Jenő már régen rávilágított arra, hogy az antiszociális agresszió és a szorongás ugyanannak a jelenségnek két oldala, továbbá, hogy a szorongó vagy az agresszív személyiség kialakulása többé-kevésbé jól körülhatárolható nevelői magatartás következménye. ${ }^{10} \mathrm{E}$. S. Schaefer (1959) nyomán a pszichológusok általánosan elfogadják, hogy a nevelői magatartás két dimenzión ábrázolható. Az egyik a gyermek testilelki szabadságának korlátozására vonatkozik, vagyis annak mértékére: fontos szempont, hogy a szülő által felállított szabályok milyen mértékben és mekkora súllyal nehezednek a gyermekre. Ez a dimenzió az engedékenység és a korlátozás két végpontja között helyezkedik el. ${ }^{11} \mathrm{~A}$ korlátozó szülő csak a saját szabályai mentén tû́ri meg a gyermek viselkedését, elvárja tőle, hogy mindenhol és minden körülményben pedánsan viselkedjen, ügyeljen a rendre és a tisztaságra, viselkedjen úgy, akár egy „kis felnőtt”. Értelemszerűen az engedékeny szülő ennek az ellenkezője. A másik dimenzió, a nevelő ún. emocionális viselkedését mutatja meg, melynek két végpontja a meleg és a hideg jelzővel jellemezhető leginkább. A meleg szülői magatartás a gyermek felé elfogadó, megértő, szeretetteljes, sosem alkalmaz fizikai büntetést, dicséretet viszont annál többet. A hideg szülői magatartásra azonban ennek az ellentettje jellemző. „A két dimenzió szélső értékeinek kombinációi négyféle attitűdöt eredményeznek - meleg-engedékeny, hideg-engedékeny, meleg-korlátozó és hideg-korlátozó -, melyek közül az elsö kettő az agresszió, az utóbbi kettő a szorongás irányában befolyásolja a személyiség alakulását."12

\footnotetext{
${ }^{7}$ Rita L. Atkinson - Richard C. Atkinson - Edward E. Smith - Daryl J. Bem - Susan Nolen-Hoeksema, Pszichológia, Osiris Kiadó, Budapest, 1999, 510. p.

${ }^{8}$ Dr. Bagdy Emőke, Családi szocializáció és személyiségzavarok, Tankönyvkiadó, Budapest, 1986, 14. p.

${ }^{9}$ Dr. Bagdy Emőke, Családi szocializáció és személyiségzavarok, Tankönyvkiadó, Budapest, 1986, 15. p.

${ }^{10}$ Dr. Ranschburg Jenő, Félelem, harag, agresszió, Tankönyvkiadó, Budapest, 1979, 135. p.

${ }^{11}$ Dr. Ranschburg Jenő, Félelem, harag, agresszió, Tankönyvkiadó, Budapest, 1979, 136. p.

12 Dr. Ranschburg Jenő, Félelem, harag, agresszió, Tankönyvkiadó, Budapest, 1979, 136. p.
} 


\section{A pedagógus, mint nevelő, a pedagógusi attitúdök}

Nem véletlen, hogy a köznevelés rendszerében egyre nagyobb hangsúlyt kap a „nevelés”, hiszen a jólneveltség az alapköve a tudás elsajátításának is. Ma már tudjuk, hogy az önmegvalósítás és a boldogság nemcsak értelmi képesség (IQ) kérdése, hanem emellett fontos szerepe van az ún. érzelmi intelligenciának (EI vagy $\mathrm{EQ}$ ) is. „Az érzelmi intelligencia a képességek azon fajtája, ami a saját és mások érzelmeinek érzékelésével, kezelésével és pozitiv befolyásolásával kapcsolatos." ${ }^{13} \mathrm{~A}$ fejlett érzelmi képességű emberek általában boldogabbak, elégedettebbek, kiegyensúlyozottabbak és lényegesen sikeresebbek társaiknál. Kutatások bizonyították, hogy az iskolában elsajátított képességek közül a megtanult tananyag csupán 20\%-ban befolyásolja pozitívan a későbbi sikerességet, míg a többi $80 \%$ leghangsúlyosabb eleme az érzelmi intelligencia, amire sajnos az oktatási intézmények döntő többségében még mindig nem szentelnek kellő figyelmet. ${ }^{14}$

A nevelői attitúdöket a pszichológiában már többen, különböző megközelítésekben tárgyalták. „A kutatások egyaránt azt bizonyították, hogy az autokrata nevelői magatartás a nevelői célkitüzésekkel ellentétes irányú reagálást idéz elő a gyermekeknél, hosszú távon mindenképpen káros. Az oldott légkör, a kiegyensúlyozott tanár-diák kapcsolat, a vélemények kifejezésének a lehetősége pedig alkalmat teremt az összehasonlításra, egymás megismerésére a tanulók között."15 A pedagógus attitúdje éppen úgy, ahogy a szülői-nevelői attitűd, komoly befolyással bír a fejlődő lélek személyiségének alakulására, azonban lényegesen nehezebben mérhető. Egyrészt azért, mert míg a gyermek szülei normál esetben állandó tényezők, vagy legalább is közel azok, a pedagógusok már akár évente is váltogathatják egymást, másrészt mert a tanárokkal szembeni elvárások igen szerteágazóak, valamint igen sokféle képességnek kell birtokában lenniük, hogy sikeresnek nevezhessük őket. A pedagógusi attitúdök elhatárolása és meghatározása így sokkal problematikusabb, mint a szülői attitúdöké, pláne az, hogy azok milyen irányban és mértékben hatnak a gyermek személyiségfejlődésére. Összességében mégis elmondható, hogy a pedagógusok stílusjegyeik alapján többé-kevésbé szintén behatárolható típusokba sorolhatók. Ha igazságosak szeretnénk lenni, akkor annyiféle stílust kellene felsorolni, ahány pedagógus létezik, de ugyanez igaz a szülókre is. Vizsgálatokat azonban csak úgy végezhetünk, ha meghatározunk néhány alapvetően jellemző (gyakran szélsőséges) attitúdöt, melyek segítségével, ha nem is tökéletesen, de mérhetővé tesszük a különböző pedagógusi beállítódásokat. Ha a szülői attitűdök logikája mentén indulunk, akkor elfogadhatjuk a tényt, hogy létezik a tanárok között is a diákokkal szemben elfogadó, valamint elutasító típus, ezt a dimenziót nevezhetjük ugyanúgy melegnek illetve hidegnek (affektív, vagyis érzelmi sík). Ezen kívül fontos még a diák testi illetve szellemi korlátozásának mértéke, ez a dimenzió az engedékenység illetve a korlátozás két végpontja között helyezkedik el (kognitív sík). ${ }^{16}$ Ennek megfelelően szintén négy típust különíthetünk el. A meleg-engedékeny attitűd az ún. megengedő tanártípus, aki elfogadó a diákokkal szemben, rossz magaviseletüket is meglehetősen jól tolerálja, vagy legalább is látszólag jól. A hidegengedékeny attitúddel rendelkező tanár minden elemében elhanyagoló, mind a diákok szellemi-lelki fejlődését illetően, mind a követelmények tekintetében. A meleg-korlátozó attitűdöt képviselő tanár az ún. irányító vagy autoritatív típus. Amellett, hogy gyermekközpontú, követelő is egyben, vagyis határozottan, következetesen irányító. A hideg-korlátozó attitúddel rendelkező pedagógusokat hívjuk általában tekintélyelvűnek vagyis autoriternek. Ez a pedagógustípus egyáltalán nem gyermekközpontú, inkább egocentrikus, minden erejét és energiáját abba fekteti, hogy a tekintélye ne szenvedjen csorbát.

\footnotetext{
${ }^{13}$ https://hu.wikipedia.org/wiki/\%C3\%89rzelmi intelligencia

${ }_{14} \mathrm{https://mindsetpszichologia.hu/2017/11/29/mi-is-az-az-eq-es-hogyan-fejleszthetjuk/}$

${ }^{15} \mathrm{http}: / /$ magyarpedagogia.hu/document/2 133 Sallay\%20Hedvig.pdf, 201. o.

${ }^{16}$ https://www.tankonyvtar.hu/hu/tartalom/tamop425/2011 0001520 neveleslelektan/ch02s02.html
} 


\section{Az önértékelés fogalma, színterei}

Vajon jól ismerjük magunkat? Kit könnyebb megismerni: önmagunkat vagy másokat? Ezt a kérdést nyilván mindenki gondolkodás nélkül meg tudná válaszolni: „Egyértelmú: önmagamat!” Pedig ez az esetek döntő többségében nem így van. Nagyon nehéz önmagunkat feltárni és megismerni, szinte mindig tudatos törekvés eredménye, sőt, gyakran csak szakember segítségével lehetséges. Hogy miért van ez így? Személyünket illetően sokféle visszajelzést kapunk a világból, amelyek sajnos nem mindig helyesek vagy igazságosak, de önmagunkat leginkább ennek segítségével tudjuk beazonosítani: hogy mások hogyan vélekednek rólunk, hogyan viselkednek velünk, hogyan reagálják le tetteinket, gondolatainkat. A gyermek születésétől fogva a felnőttektől és a kortárscsoporttól kapott visszajelzésekből tudja meg, hogy jó vagy rossz, amit csinál, hogy ügyes-e vagy sem, szép-e vagy sem, okos-e vagy sem. Azonban ne felejtsük el, hogy azok az emberek, legyen az gyermek vagy felnőtt, szülő vagy tanár, barát vagy ellenség, akik visszacsatolást küldenek sem tökéletesek, nem biztos, hogy reálisan ítélnek meg bennünket, nem biztos, hogy helyesen reagálnak tetteinkre, viselkedésünkre. Ebből kifolyólag egy gyermek önmagáról alkotott képe (pláne, ha ebben külső megerősítést is kap) lehet egészen irreális is, sokkal rosszabbnak és ügyetlenebbnek érezheti megát, mint amilyen valójában és fordítva. Az énkép ily módon tehát lehet pozitív és negatív. „Pozitív énkép és reális önértékelés esetén alacsony szorongási szint jellemzi az egyént, kedvezőbb a tanulási motivációja, jobbak a kognitív teljesités feltételei, jó az egyén együttmüködési készsége. A negativ énkép és az alacsony önértékelés megnehezíti a gyerekek iskolai, majd később a társadalmi beilleszkedését, az egyéni fejlődésnek újabb és újabb korlátait épiti fel." ${ }^{17}$ Emellett gyakran okoz problémát, hogy a gyermekek, fiatalok nem kapnak kellő segítséget abban, hogy felismerjék erősségeiket, tehetségüket, így megfosztva őket attól, hogy megvalósíthassák önmagukat. Manapság egyre szélesebb körben okoz komoly kihívást az iskolákban és a munkaerőpiacon is a motiválatlanság, a céltévesztés, valamint az ennek következtében kialakuló szorongás és depresszió, amely kellő szakértelemmel és egy kis odafigyeléssel kiküszöbölhető lehetne. Önmagunk ismerete, adott esetben folyamatos értékelése, vizsgálata tehát sikerünk egyik kulcsa is egyben, és egyéni sikerünk közösségi sikerré is válik, amint hasznos tagjává válunk a társadalomnak. Nekünk, pedagógusoknak kiemelt célként kell kitúznünk a tehetségek felismerését, motiválását, orientálását, mely elviekben adott és kötelező, azonban tapasztalataim szerint nálunk még mindig gyerekcipőben jár. Az önértékelés tehát nem más, mint „az ember kritikai megítélése és minősitése önmagáról, képességeiről, tevékenységéről, magatartásáról. A folyamatos önmegfigyelésen és önellenörzésen alapuló önértékelés lehetővé teszi az egészséges, személyiségre jellemző önismeret és önbizalom kialakulását, az önirányitás képességének fejlődését."18 A kudarcélmények jelentős részét kiküszöbölhetnénk, ha már a kezdetektől, gyermekkortól fogva elsajátítanánk a helyes önértékelés és önellenőrzés képességét: „Fontos, hogy már 1. osztálytól kezdve helyt adjunk az önértékelésnek. Fontos kialakitani a tanulóban, hogy saját érdeke a helyes önellenörzés és önértékelés megtanulása." 19

\section{Az alacsony valamint a reális önértékelés várható hatásai}

Mikor valamilyen okból kifolyólag, mint például következetlen szülői vagy pedagógusi nevelés, sérül egy gyermek önértékelése, akkor viselkedése gátolttá válik, személyiségében pedig negatív kép alakul ki önmagáról. Ennek nyilván számtalan megjelenési formája van, attól függően, hogy ez az ún. sérülés

\footnotetext{
${ }^{17}$ Sipos Imre, A közoktatási intézmény hatékonysága, Budapesti Múszaki és Gazdaságtudományi Egyetem, Budapest, 2013, 66. p.

${ }^{18}$ Báthory Zoltán - Falus Iván: Pedagógiai lexikon III., Keraban, Budapest, 1997, 102. p.

${ }^{19}$ https://hu.wikipedia.org/wiki/\%C3\%96n\%C3\%A9rt\%C3\%A9kel\%C3\%A9s
} 
a személyiségfejlődés mely szakaszában, milyen okból keletkezett. Az alacsony önértékelés következtében csökken a kezdeményezőképesség, a kudarckerülő viselkedés válik jellemzővé, továbbá a félénkség, szorongási hajlam, pesszimizmus, magány, vagy éppen valamiféle antiszociális agresszió. Megfelelő szülői illetve pedagógusi segítség hiányában személyiségfejlődése minden bizonnyal megreked, nem tud kialakulni egészséges „felnőtt” önképe, nem tudja se konfliktusait, se kudarcélményeit, sem pedig társas kapcsolatait felnőtt módon, éretten kezelni, felnőttként is éretlen, gyakran felelőtlen viselkedés lesz jellemző. Az önmegvalósítás lehetősége ily módon a minimálisra csökken, melynek következménye a boldogtalanság, az örökös elégedetlenség, evészavarok, megkeseredettség, reménytelenség, depresszió, néha öngyilkosság vagy bűnözés.

A reális önértékeléssel rendelkező fiatal vagy felnőtt éppúgy, mint az alacsony önértékeléssel rendelkező viszonylag jól felismerhető. Míg az önbizalomhiányos ember ingerlékeny, cinikus, addig a reális önértékelésű kiegyensúlyozott, nyugodt, inkább humoros, jókedvű. Általánosságban elmondható, hogy egészséges öniróniával rendelkezik, nem sértődékeny, nem tüskés, jól fogadja az építő jellegű kritikákat, magabiztosan hárítja az őt ért igazságtalanságokat. Társas kapcsolatai az életkorának megfelelően működnek. Nincs túlzott szexuális túlfútöttség vagy gátoltság, népszerúség hajhászás, vagy éppen magány. Általában jobban megválogatja barátait, önmagához és saját értékrendszeréhez megfelelő társakat választ, nem keveredik „,rossz társaságba”, hiszen tudja, hogy az őrá nézve káros lehet. Az élet minden területén felnő, tehát érett gondolkodású felnőtt lesz, ami nagymértékben megkönnyíti későbbi életét. A munka világában is egyre inkább tapasztalható, hogy nem feltétlenül a szakmai tapasztalattal, nagy tudással rendelkező munkaerőt részesítik előnyben, hanem azokat, akik érett, felnőtt gondolkodással rendelkeznek, önértékelésük nem túl alacsony, de nem is irreálisan magas (magamutogató), akik társas kapcsolataikat megfelelően kezelik, jó csapatjátékosok, magas az érzelmi intelligenciájuk, empatikusak, az élet minden területén kiegyensúlyozottak, hajlandók fejlődni, tovább képezni magukat, megbízhatóak, motiváltak és motiválók egyben.

\section{Önértékelés 14-18 éves korban}

A 14-18 éves kort gyakran emlegetjük úgy, mint a fejlődő szubjektum legkritikusabb időszaka, vagy éppen a lázadás időszaka, a dackorszak egy kései, de igen viharos formája, a felnőtté válás, az önállósodás kezdete..., azaz kamaszkor. Valójában azonban ideális esetben, példamutató családi környezetben és szakértő pedagógusi munkával ez az önállósodási folyamat már az óvodában, legkésőbb a kisiskolás korban meg kell, hogy kezdődjék. Ha a gyermek hozzászokott ahhoz, hogy bíznak benne szülei, tanárai, hisznek abban, hogy feladatait önállóan is el tudja végezni, de ha segítségre szorul, van kihez forduljon, bármikor kap iránymutatást, segítséget, akkor ezt az ún. felnőttektől kapott egészséges önbizalmat és stabilitást tovább viszi magával a kamaszkorba is, így azt sokkal konfliktusmentesebben vészeli át, mint szülői vagy pedagógusi hanyagság vagy éppen túlfélés közepette. Hogy mennyire reális a gyermek önértékelése, az is javarészt attól függ, hogy mennyire lett megtanítva neki gyermekként, hogyan értékelje önmagát az élet minden területén, hogyan térképezze fel hiányosságait, hogyan fogadja el azokat és hogyan orvosolja, hogyan dolgozza fel a kritikát és a kudarcélményeket, hogyan keressen kiutat a nehézségekből. És itt már a szülő mellett a pedagógusnak is óriási szerepe van. Ha a szülő valamilyen okból nem is teszi meg, a pedagógus már kisiskolás korban megtaníthatja a gyermeket a helyes önértékelés képességére, ami egy életre szóló segítség, hogy ne értékelje alul, se túl önmagát, mert mindkettő komoly konfliktusokat, nehézségeket fog jelenteni a felnőtt társadalomban. Kamaszkorban szükségszerúen átrendeződik, megváltozik a szülő-gyerek 
kapcsolat, mivel a fiatal életében megnövekszik a kortársakkal töltött idő a szülővel töltött idő rovására. A legtöbb konfliktusa a gyermeknek ilyenkor a szülőkkel van, mely általában kiskamaszkorban meglehetősen viharosan indul, aztán az idő előrehaladtával, ahogy egyre kevesebb időt tölt otthon, alábbhagy valamelyest. ${ }^{20}$ Kamaszkorban derül ki először igazán, hogy a szülő megfelelően készítette-e fel gyermekét a felnőtt életre.

A szülői és az iskolai eredményesség mellett kiemelkedő befolyással bír a fejlődő lélek önértékelésére a kortárscsoport, amelynek tagja. Rendkívül sokat ad hozzá az önbizalomhoz, ha a fiatal népszerú az ellenkező nemúek körében, vagy ha sikerül olyan baráti társaság tagjává válni, ahol közös az érdeklődés, ha az osztálytársak elismerik, kedvelik. Tapasztalatok szerint a szülői agresszió mellett a kortárscsoport agressziója is rendkívül negatívan befolyásolja az önértékelést. Igen jellemző a korosztályra a "klikkesedés” illetve "bandázás”, ennek következtében a szülői kontroll is - olykor drasztikusan - lecsökken. Mindettől függetlenül azonban elmondható, „hogy a legtöbb serdülő (a kortárscsoport hatásaitól függetlenül továbbra is) osztozik szülei értékrendjében. A szülők és a serdülők között felmerülö nézeteltérések rendezésének legföbb módja a párbeszéd, nem pedig a nyílt konfliktus és a visszautasítás." 21

\section{A választott vizsgálati módszerek, a vizsgált tanulók}

A tanulókat a Self-Esteem Inventory (SEI) önértékelési kérdőívvel ${ }^{22}$ vizsgáltam meg. A kérdőív általános iskolás és középiskolás korú gyermekek vizsgálatára alkalmas. A kérdőív $4+1$ alskálát tartalmaz: négy az önértékelés egyes összetevőit tartalmazza (self, társak, otthon, iskola), az ötödik pedig (amelyet nem számolunk bele az általános önérték-indexbe) a lie-scale, azaz a társadalmi elvárásokkal való konformitást kifejező kérdéscsoport. A szülői-nevelői stílus percepciójának vizsgálatára az ún. IMAS tesztet ${ }^{23}$ alkalmaztam, mely eljárás tíz kritikus helyzet leírását tartalmazza. A válaszadó feladata az, hogy a helyzetek után megadott 4-4 megoldási lehetőség közül (amelyek a Schaefer-modell négy mezőjének felelnek meg) mind a tíz esetben válassza ki azt, amit véleménye szerint az adott helyzetben szülei tennének. Szükséges megjegyezni, hogy az eljárás nem a szülők tényleges attitűdét vizsgálja, hanem hogy a tanulók szubjektív tapasztalatában hogy jelenik meg a szülők nevelési stílusa. A pedagógusi attitűdök vizsgálatára egy saját magam által készített kérdőívet használtam (3. sz. melléklet). Itt az ún. Likert-skálát alkalmaztam, ami az egyik legegyszerúbb formája az információgyújtésnek, és kiértékelni is roppant egyszerú. Összesen 24 állítást tartalmaz a kérdőív, melyből 12 a pedagógus emocionális viselkedését állítja középpontba, ebből megtudhatjuk, hogy a pedagógus viselkedése a diákkal szemben általában inkább elfogadó vagy elutasító, a másik 12 pedig olyan állításokat fogalmaz meg, mely segít kideríteni, hogy az őt tanító pedagógusok általánosságban korlátozók vagy engedékenyek.

A vizsgálatot a Tatabányai Szakképzési Centrum Bláthy Ottó Szakgimnáziuma, Szakközépiskolája és Kollégiumában végeztem el. A szakközépiskolások mindannyian 11. évfolyamos fiúk voltak, a 30 fős létszám ( $N=30$, ebből 30 fiú, 0 lány) két külön osztályból tevődött össze (átlagéletkor: 17,6 év). A szakgimnáziumosok szintén 11. évfolyamos fiúk voltak, a 30 fős létszám ( $N=30$, ebből 30 fiú, 0 lány) itt három különböző osztályból tevődött össze, vizsgálatukat pedig két részletben végeztem el

\footnotetext{
${ }^{20}$ Michael Cole - Sheila R. Cole, Fejlődéslélektan, Osiris Kiadó, Budapest, 2003, 631. p.

${ }^{21}$ Michael Cole - Sheila R. Cole, Fejlödéslélektan, Osiris Kiadó, Budapest, 2003, 639. p.

22 https://derep-k.drhe.hu/39/2/Pszichologiai-vizsgalati-modszerek-gyujtemenye-javitott-kiadas2017-nyomda20170830.pdf, 96. o.

${ }^{23}$ http://real-j.mtak.hu/4951/1/Pszichologia 04.pdf, 538. o.
} 
(átlagéletkor: 17,5 év). A felmérésben azért szerepelnek kizárólag fiúk, mert az intézményben a 11. évfolyamos szakközépiskolai osztályokban javarészt csak fiú tanulók vannak, így az összehasonlítás kedvéért választottam szintén 11. évfolyamos szakgimnáziumos fiúkat. Mivel ebben az életkorban a lányok általában érzelmileg fejlettebbek, úgy gondoltam, ez lehetetlenné tenné a két csoport racionális összehasonlítását. Továbbá azért döntöttem a 11. évfolyam mellett, mert a 9-10. évfolyamos tanulók általánosságban éretlenebbek, a 12. évfolyamosok között viszont nagyon sok 19-20 éves tanuló található.

\section{A vizsgálati eredmények kiértékelése}

A vizsgált tanulók kérdőíveinek kiértékelését követően különböző statisztikákat és összehasonlításokat végeztem el, hogy minél pontosabban meg tudjam határozni, milyen irányban és milyen mértékben befolyásolja a szülői illetve a pedagógusi attitűd a szakközépiskolai és szakgimnáziumi tanulók önértékelését.

\section{Az önértékelési kérdőív kiértékelése}

\section{1. ábra: A társadalmi elvárásokkal való konformitás, azaz a lie-scale}

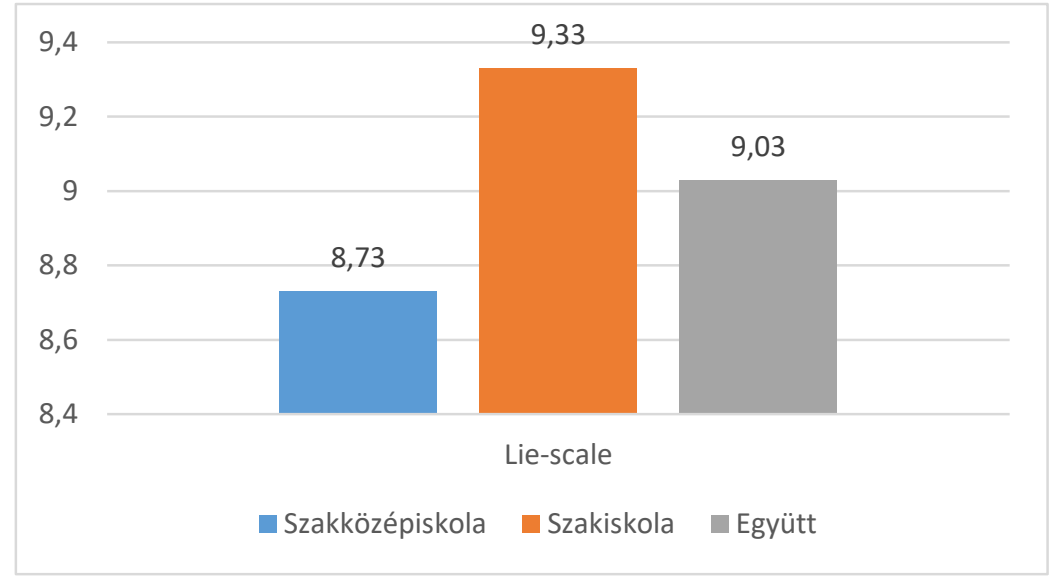

Az önértékelési kérdőívek esetében elsőként a lie-scale értékeket említeném, mely valójában nem számít bele az önérték-indexbe. Ha nem számít bele, akkor vajon miért van rá szükség? Valójában ennek a skálának az itemei jelzik a tanulónak a társadalmi elvárásokkal szembeni konformitását, vagyis azt, hogy mennyire veti magát alá ezeknek az elvárásoknak. Minél magasabb pontszámot ér el a tanuló ennél a skálánál, annál függetlenebb gondolkodású, vagyis annál őszintébb másokhoz és önmagához, így a többi válasza is nagy valószínűséggel őszintébb. Valójában ez az érték az önérték-indexen számszerűen nem változtat, ez csak a kiértékelő számára információ értékú. Ez az érték szakközépiskolások esetében alacsonyabb, akik az összesen szerezhető 16 pontból átlagosan 8,73 pontot értek el, míg a szakgimnáziumos tanulók 9,33 pontot (1. ábra). Ez a nem túl jelentős különbség arra utalhat, hogy a szakgimnáziumi tanulók kismértékben őszintébbek voltak, mely úgy gondolom, az önérték-indexek alakulására is hatással lehetett: részben emiatt lehetséges, hogy a szakközépiskolai tanulók önérték-indexe $(73,93)$ valamelyest magasabb értéket mutat, mint a szakgimnáziumi tanulóké $(69,0)$. 


\section{2. ábra: A vizsgált tanulók és az átlag önérték-indexeinek felosztása és azok összehasonlítása}

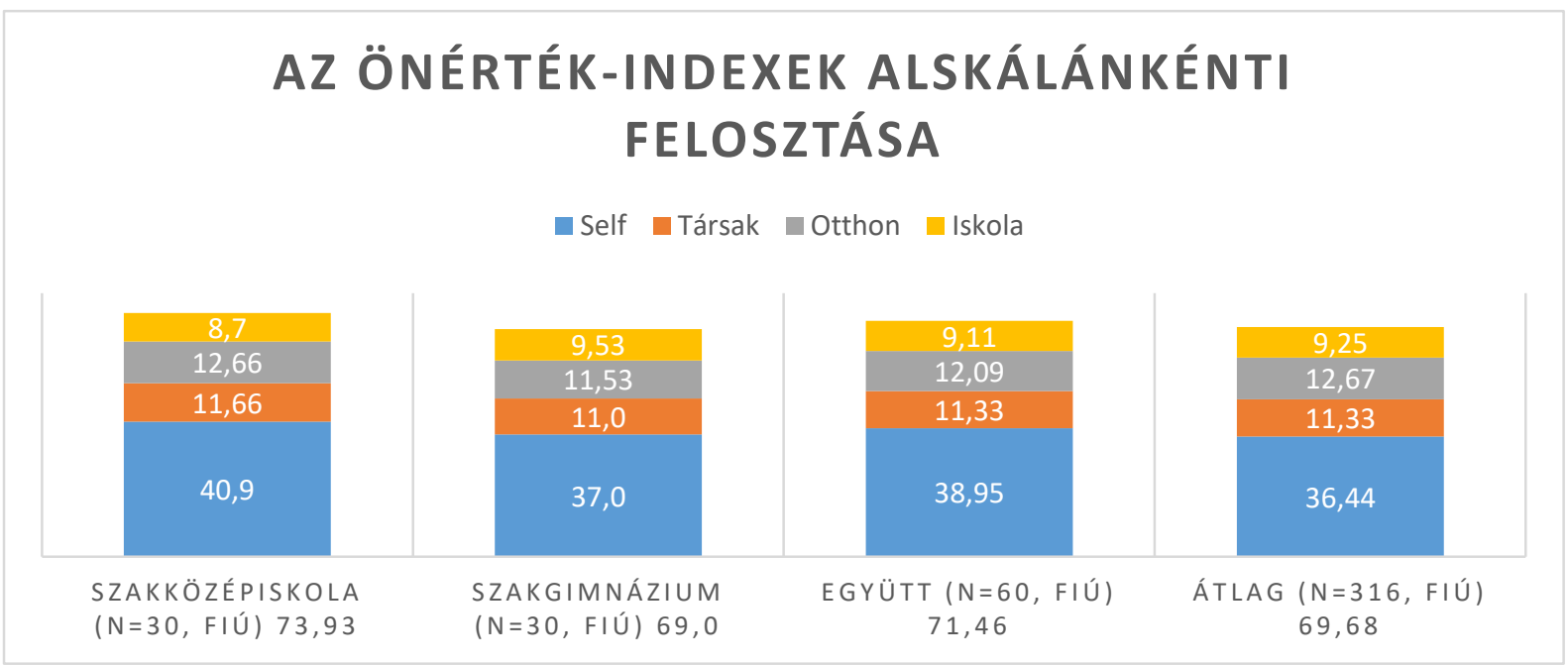

Az önérték-indexek összetevői (2. ábra) azt mutatják, hogy a szakközépiskolai tanulók az iskolai teljesítményükkel kevésbé elégedettek, mint a szakgimnáziumosok, melynek legvalószínúbb oka, hogy a szakközépiskolába érkező tanulók nagy általánosságban gyengébb képességűek. A vizsgálat ezt a jelenséget látványosan igazolta. Ellenben a családi és a társas kapcsolatok is magasabb értékeket mutatnak a szakközépiskolások esetében, és e két összetevő, mint ahogy már említettem, általánosságban nagyobb befolyással bír a tanulók önértékelésére ebben az életkorban, mint az iskolai eredményesség, többek között ezért sem meglepő, hogy a szakközépiskolai tanulók önérték-indexe átlagosan magasabb, mint szakgimnáziumos társaiké. Ha összevetjük a kapott értékeket az átlaggal (1. sz. melléklet), akkor láthatjuk, hogy a 60 vizsgált tanuló összesítve hasonló értékeket produkált, mint az átlag. Érdemes megvizsgálni továbbá az önérték-indexek összetevőinek százalékos eloszlását (3. ábra). Ha a self-adatokat részarányosan átalakítjuk, hogy a többi alskálához hasonló értékben szerepeljen, akkor ki tudjuk számolni, hogy a vizsgált tanulók esetében mely önérték-összetevők dominálnak jobban és melyek kevésbé. Látható, hogy a szakgimnáziumosok iskolai eredményességükkel az átlagnál jobban meg vannak elégedve, azonban mind a társas, mind az otthoni kapcsolataikkal kevésbé. Érdekes eredmény, miszerint önérték-indexük mégis valamelyest magasabb az átlagnál, de még így is elmarad a szakközépiskolai tanulókétól.

\section{3. ábra: A vizsgált tanulók és az átlag önérték-indexeinek összetevői százalékos eloszlásban}

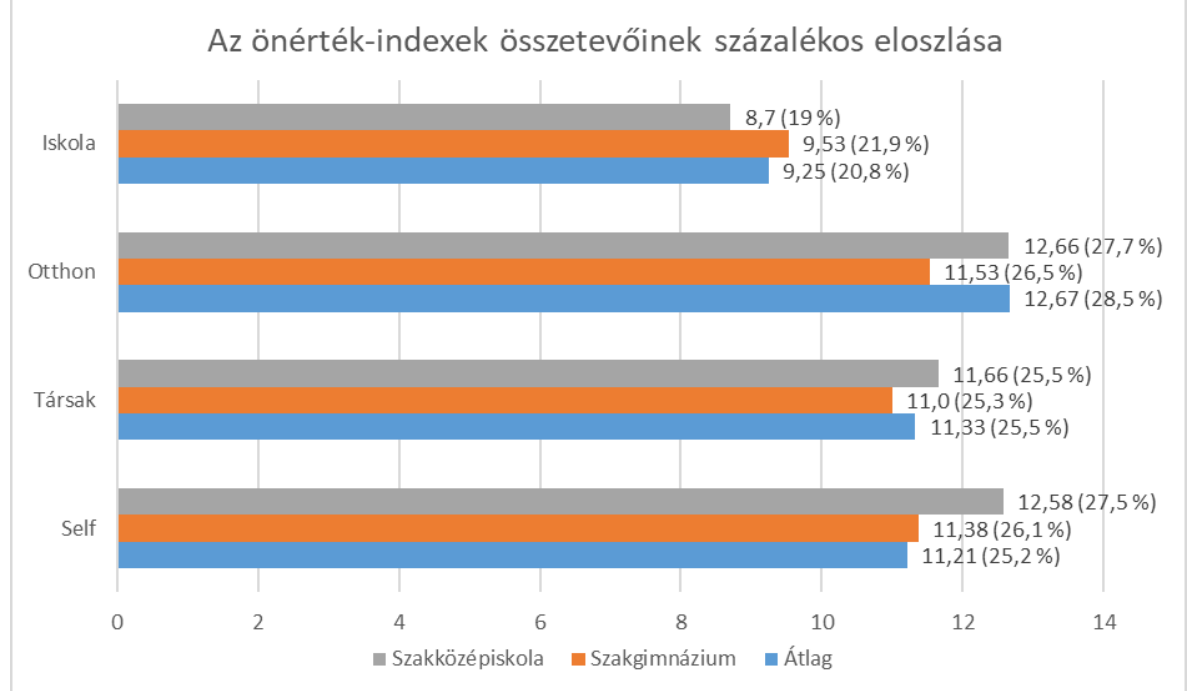




\section{A szülői attitúd és a tanulói önértékelés, személyiségfejlődés összefüggései}

A szülői-nevelői attitűdöket vizsgáló kérdőív kiértékelését követően egyértelműen kimondható, hogy mind az édesapák, mind az édesanyák esetében a leggyakoribb szülői attitǔd a meleg-engedékeny. Apák esetében (4. ábra) minimális eltérés tapasztalható e tekintetben a többi attitűd-típus esetében is, a vizsgált tanulók édesapja itt is hasonló tendenciát mutat mindkét iskolatípusban, a szakgimnáziumi tanulók esetében valamelyest több a meleg-korlátozó apa, kevesebb a hideg-korlátozó, míg a szakközépiskolai tanulók esetében ez éppen fordítva igaz.

\section{4. ábra: Az apa attitüdje a vizsgált tanulók körében}

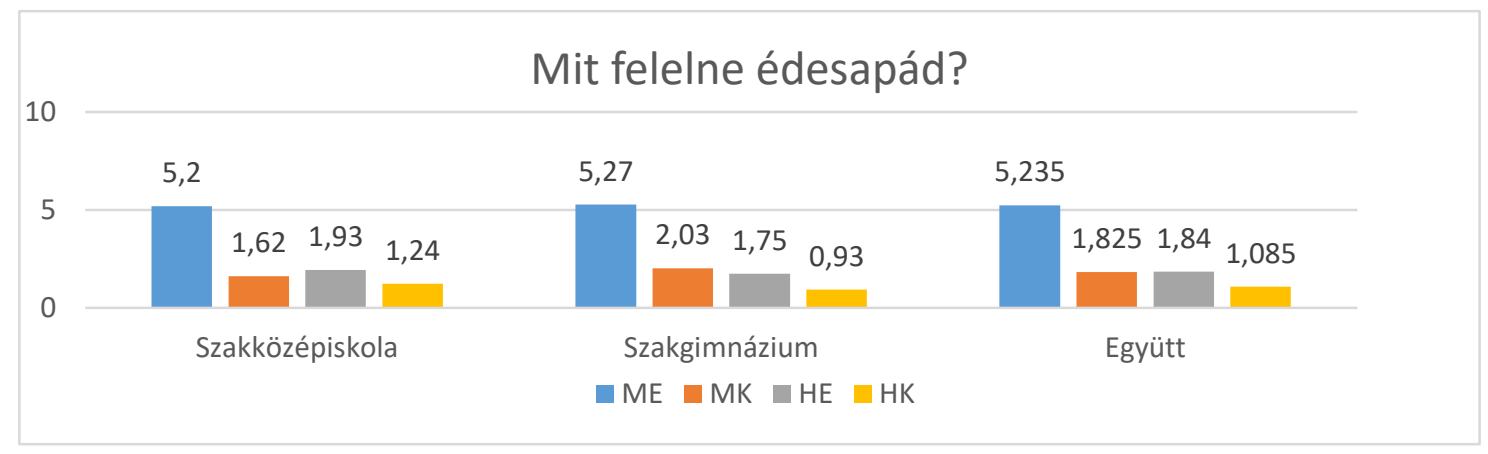

\section{5. ábra: Az anya attitűdje a vizsgált tanulók körében}

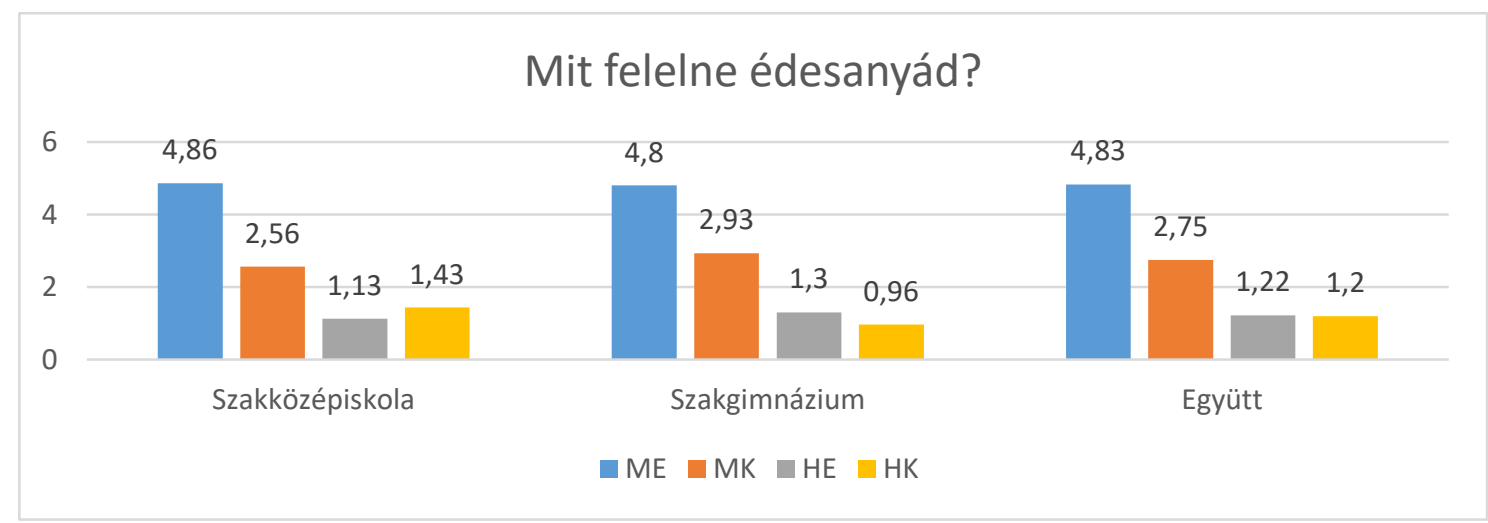

Az édesanyák esetében (5. ábra) is minimális eltérés tapasztalható, talán szembetűnő, hogy szakközépiskolai tanulók esetében némileg több a hideg-korlátozó anya, míg a szakgimnáziumi tanulók esetében a meleg-korlátozó.

Ha összevetjük az eredményeket és lebontjuk a melegség és engedékenység mértékére, akkor láthatjuk, hogy összességében az anyák melegebbek, de korlátozóbbak, az apák viszont valamivel hidegebbek, de jóval engedékenyebbek az anyáknál (6. ábra).

\section{6. ábra: A vizsgált tanulók által érzékelt szülői melegség és engedékenység mértékének az összehasonlítása}

\section{A melegség és az engedékenység mértéke}

\section{a 10-es skálán}

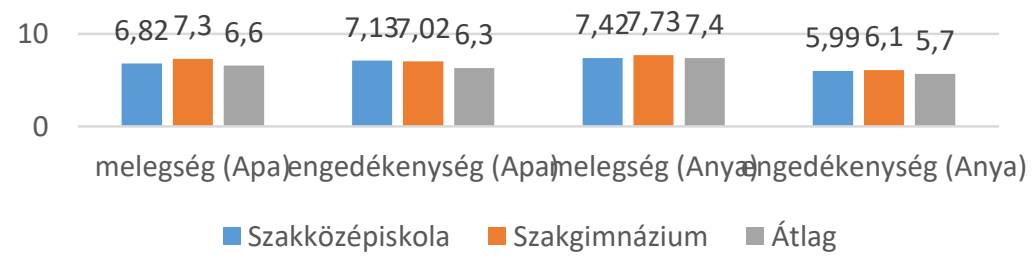


Ha a kapott értékeket összevetjük az átlaggal (2. sz. melléklet), tisztán kivehető, hogy az általam vizsgált tanulók saját szüleiket valamivel melegebbnek és engedékenyebbnek érzékelik, mint az átlag. Ennek oka talán az lehet, hogy sokan elmúltak már 18 évesek, és jellemző ebben az életkorban, hogy a szülőkkel való viharos viszonyok csendesedni kezdenek, így közvetlenebbé válik kapcsolatuk, a szülők engedékenyebbé válnak. A szakközépiskolai tanulók önérték-indexének alakulására az is pozitív hatással lehet, hogy a vizsgálat szerint valamivel jobban egyetértenek szüleik nevelési attitúdjével (7. ábra), vagyis valószínűsíthetően kevesebb az otthoni konfliktus, ezt látszik alátámasztani az is, hogy az önérték-index felosztásánál a szakközépiskolások magasabb értéket produkáltak az otthoni kapcsolatok esetében.

\section{7. ábra: A vizsgált tanulók szüleik nevelési attitúdjével való egyetértésük mértéke}

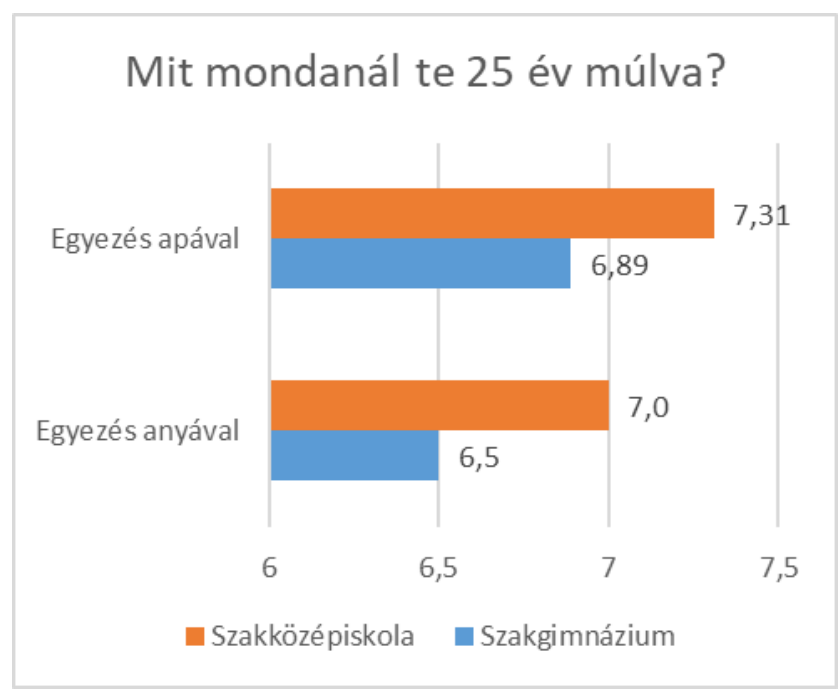

Összességében elmondható tehát, hogy a kapott önérték-indexek nagyából összhangban vannak az átlaggal, a kisebb mértékű eltéréseknek többé-kevésbé megmagyarázható okai vannak. Ha összevetem a tanulók önérték-indexeinek alakulását és a szülői attitűdöket, akkor egyértelműen megmutatkozik, hogy az olyan szülő esetében, ahol mindkettő, vagy akár az egyik szülő inkább hideg, elutasító, ott az önérték-indexek is alacsonyabbak, pl. szakközépiskolában a 11. tanuló, ahol hideg-engedékeny apa és ambivalens viselkedésű anya mellett 58-as önérték-index található, a 13., ahol hideg apa és szintén ambivalens anya mellett 64-es, vagy a 17. tanuló, ahol hideg-engedékeny apa mellett 56-os. Megfigyelhető, hogy ahol rendkívül alacsony a szülővel való egyetértés, ott is alacsonyabbak az értékek, mint például az elóbb említett 17. tanuló esetében, ahol az apával való egyetértés 10/0, az anyával 10/5, vagy a 25. tanulónál, ahol az apával 10/0, az anyával 10/2 egyetértés mellett csupán 44es önérték-index található. Alacsony önérték-indexet produkálhat a diák elfogadó szülők esetében is, de az alacsony önértékelésnek ezekben az esetekben is nyilvánvaló okai vannak, pl. a 24. tanuló esetében, ahol a társas kapcsolatok (16/2) és az iskola (16/4) is rendkívül alacsony értéket kapott, itt az önérték-index 54. A legmagasabb önérték-indexet (80 feletti) azok a tanulók érték el, ahol a szülők kivétel nélkül mind elfogadók és kevésbé korlátozók (tehát leginkább meleg-engedékenyek), ezekben az esetekben az otthon alskála is egyértelmúen magasabb értékeket mutat az önértékelési kérdőívben, pl. az 1. (otthon: 16/14, önérték-index: 82), a 2. (o: 16/16, öi: 92), a 4. (o: 16/16, öi: 92), a 9. (o: 16/14, öi: 84), a 18. (o: 16/16, öi: 90) és a 26. (o: 16/16, öi: 85) tanuló esetében. Szakgimnáziumban ugyanígy kimutatható ez a jelenség, alacsony önérték-indexet produkált a 15. tanuló, ahol az apa hideg, az anya ambivalens viselkedésű (otthon értéke 16/0), itt még a társas kapcsolatok (16/4) és az iskolai eredményesség (16/4) is rontja az értéket, önérték-indexe csupán 22. A 20. tanuló apja hideg, a tanuló 
önérték-indexe 42, a 22. tanulóé 34, itt az apa hideg, és a társas kapcsolatok (16/2) is rontják az értéket. Alacsony önérték-indexet okozhat itt is a szülókkel vagy valamely szülővel való egyetértés hiánya, pl. a már fentebb említett 20. (apa 10/3, anya 10/0) és a 22. (apa 10/1, anya 10/8) tanuló esetében, illetve a társas kapcsolatok hiánya, mint pl. a 24. tanuló esetében (16/0), akinek önérték-indexe: 36. A legmagasabb önérték-indexet itt azok a tanulók érték el, ahol a szülők elfogadók (meleg-engedékenyek vagy meleg-korlátozók), illetve az otthon alskála is magas értéket kapott, pl. a 3. (otthon: 16/14, önérték index: 82), a 7. (o: 16/16, öi: 85), a 9. (o: 16/14, öi: 84), a 10. (o: 16/16, öi: 84), a 12. (o: 16/16, öi: 86), a 13. (o: 16/14, öi: 86), a 16. (o: 16/16, öi: 85), a 17. (o: 16/14, öi: 88), a 19. (o: 16/14, öi: 83), a 23. (o: 16/16, öi: 88), a 26. (o: 16/16, öi: 90) és a 30. (o: 16/14, öi: 82) tanuló esetében.

\section{A pedagógusi attitűd és a tanulói önértékelés, személyiségfejlődés összefüggései}

A vizsgált tanulók által érzékelt pedagógusi attitúdöket másféle módszerrel igyekeztem kideríteni (3. sz. melléklet). Vizsgálatomban nem az attitúdökre, hanem a konkrét dimenziókra kérdeztem rá, vagyis arra, hogy mennyire látják engedékenynek, és mennyire elfogadónak azokat a pedagógusokat, akik a nevelésükben közvetlenül részt vettek/vesznek. Összességében elmondható, hogy mindkét csoport átlaga közepes értékeket mutat, a szakközépiskolások inkább hidegnek és korlátozónak érzik tanáraikat, míg a szakgimnáziumosok hidegnek, de engedékenynek (8. ábra). Tehát azt látjuk, hogy a tanulók által megjelölt értékek abba az irányba mutatnak, hogy tanáraik érzelmileg inkább elutasítók, és ha ez valóban igaz, akkor ez üzenetértékű számomra és a többi tanár számára is.

\section{8. ábra: A vizsgált tanulók által érzékelt pedagógusi melegség és engedékenység mértéke}

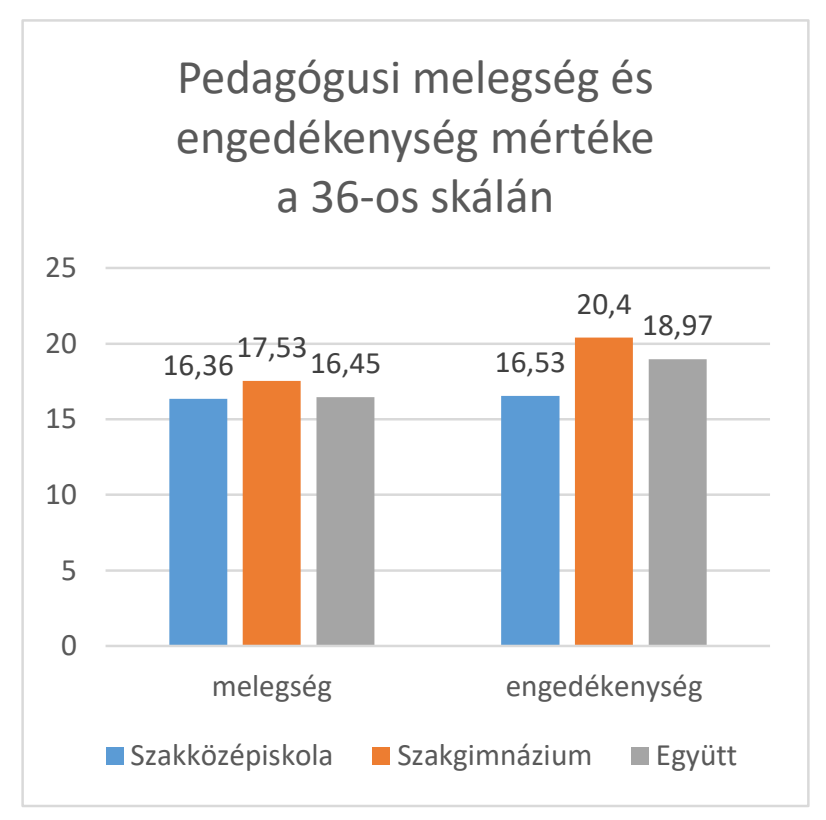

Az, hogy a szakközépiskolások korlátozóbbnak érzik a tanárokat, nem véletlen, tapasztalataim szerint náluk valóban szigorúbbnak és korlátozóbbnak kell lenni, mint szakgimnáziumban, hiszen sokkal több a viselkedészavaros, motiválatlan, sok esetben évismétlő diák közöttük. Ez persze nem jelenti azt, hogy érzelmileg is elutasítónak kellene lenni. Számomra szintén szomorú tény, hogy a szakgimnáziumosok összességében inkább elhanyagolónak (hideg-engedékeny) érzik tanáraikat. Ha összevetem az egyes tanári attitűdöket és a hozzájuk kapcsolódó tanulói önérték-indexeket (9. ábra), azt látom, hogy a 
legmagasabb önérték-index a meleg-engedékenynek érzékelt pedagógusok esetében tapasztalható mindkét csoportban, míg a legalacsonyabb szakközépiskolában a meleg-korlátozó és hideg-korlátozó esetében, szakgimnáziumban pedig egyértelműen a hideg-korlátozó esetében. Ha az összesített értéket nézzük, a legpozitívabban a meleg-engedékeny, a legnegatívabban a hideg-korlátozó attitűd hat a tanuló önértékelésére.

\section{9. ábra: A vizsgált tanulók önérték-indexeinek összehasonlítása a pedagógusi attitüdök tükrében}

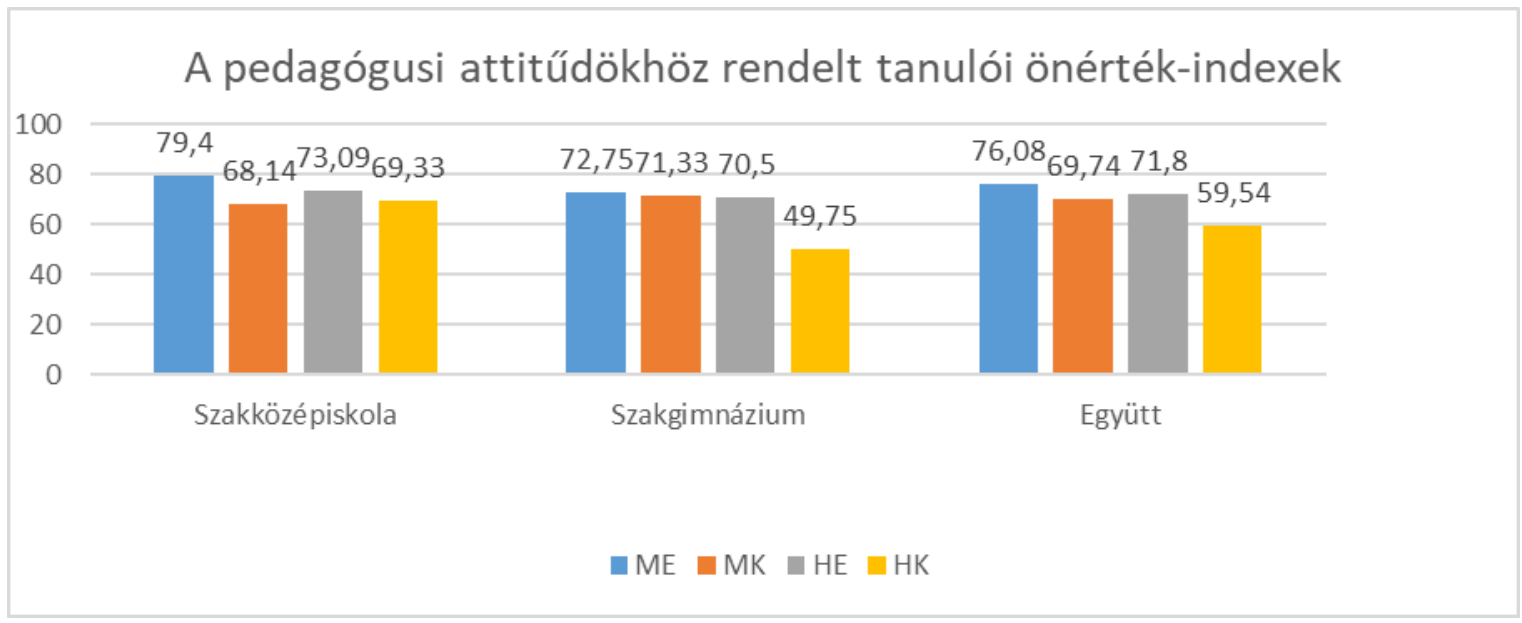

Ha ezeket az adatokat átszámítom a melegség és engedékenység mértékére és összehasonlítom a kapott önérték-indexekkel (10. ábra), akkor is ugyanezt látom, vagyis a legmagasabb önérték-indexek a meleg és az engedékeny pedagógusok esetében fordulnak elő. A pedagógus attitűdöket vizsgáló kérdőív végén feltettem a kérdést a tanulóknak, hogy véleményük szerint milyen tulajdonságokkal rendelkezik az a pedagógus, aki a legpozitívabban hat személyiségfejlódésükre. Szakközépiskolában nem mindenki válaszolt erre a kérdésre, többen is úgy feleltek, hogy „Nem tudom!”, feltételezem azért, mert valóban nem tudták eldönteni. Azok közül, akik válaszoltak, a legtöbben a kedvességet jelölték meg, illetve, sokan gondolták úgy, hogy a legmotiválóbb tanár az jó fej. Emellett számtalan tulajdonságot neveztek meg, melyek szinte mindegyike azt sugallja, hogy a jó pedagógus elfogadó, tehát emberséges, kedves, barátságos, segítőkész, figyelmes, megértő... stb., jóval kevesebb a korlátozás mértékére utaló kifejezés, mint például elnéző, engedékeny, szigorú... stb. A szakközépiskolások által a legtöbbször megemlített tulajdonságokat a 11. ábra mutatja százalékos arányban.

11. ábra: A szakközépiskolai tanulók által leggyakrabban említett személyiségfejlődést segítő pedagógusi tulajdonságok

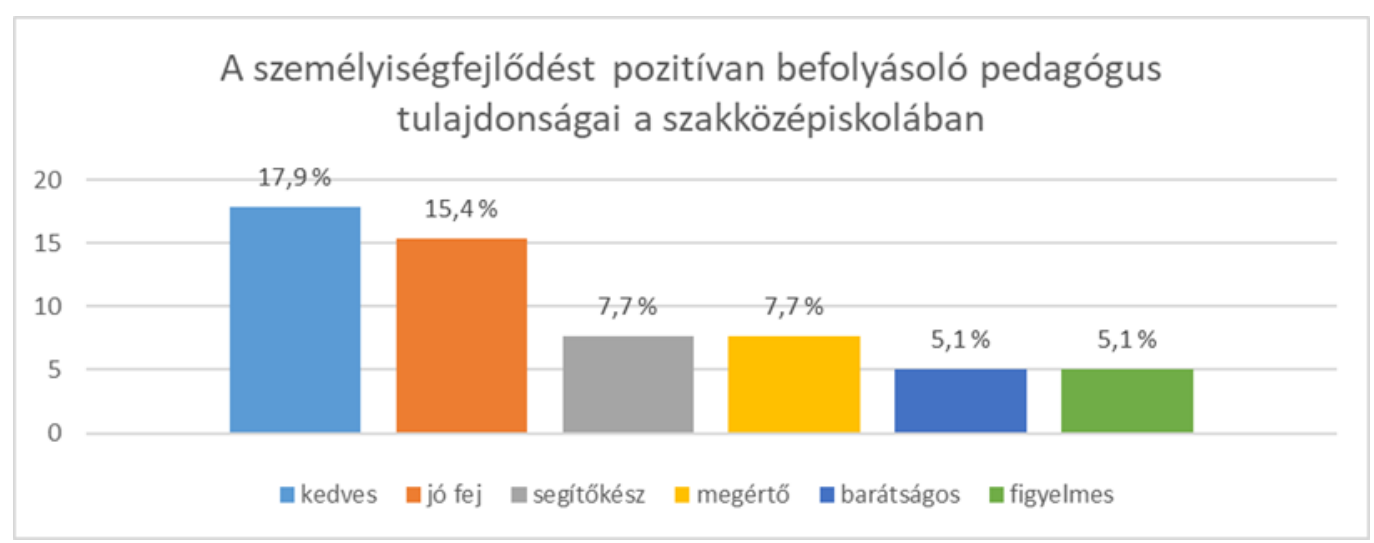


Feladat volt az is, hogy jelöljék meg a tanulók, melyik a legfontosabb tulajdonság (ezt írják az első helyre). A szakközépiskolások esetében a 12. ábra mutatja, melyik az első hat legfontosabb tulajdonság.

12. ábra: A szakközépiskolai tanulók által legfontosabbnak ítélt személyiségfejlődést segítő pedagógusi tulajdonságok

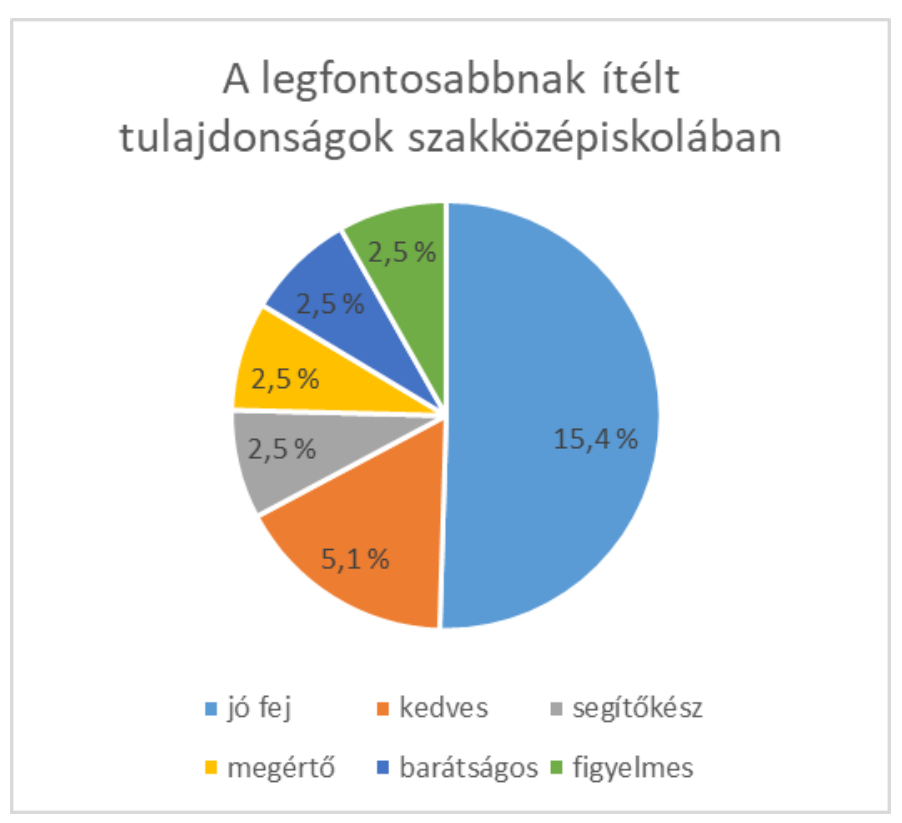

A szakgimnáziumi tanulók közül mindenki válaszolt a feltett kérdésre. Amint a 13. ábrán jól látható, válaszaik nem sokban különböznek a szakközépiskolás tanulókétól.

\section{3. ábra: A szakgimnáziumi tanulók által leggyakrabban említett személyiségfejlődést segítő} pedagógusi tulajdonságok

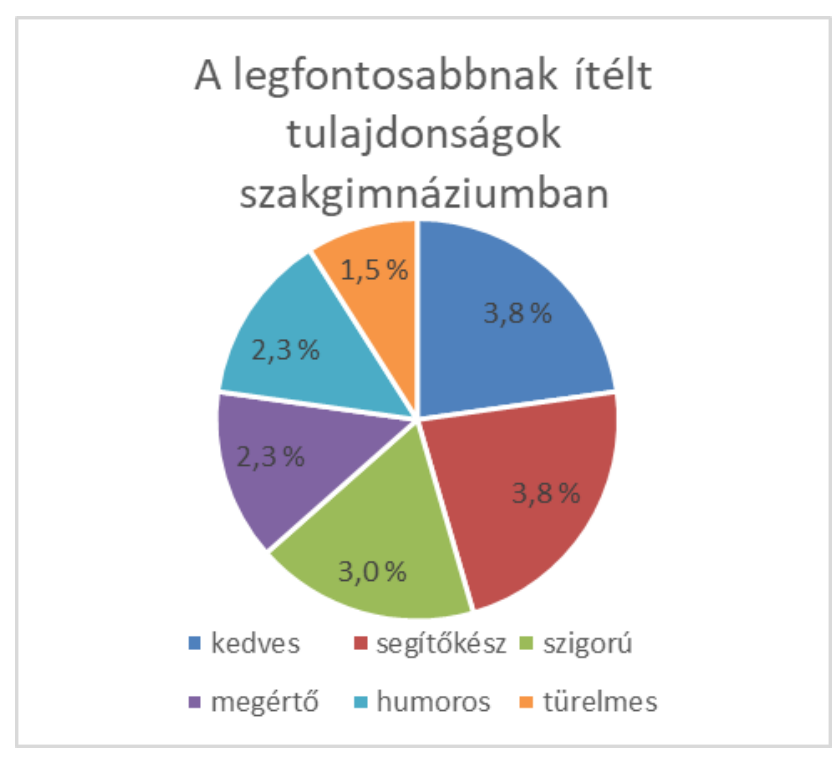

Legnagyobb százalékban itt is a kedvesség, segítőkészség, megértés szerepel, azonban érdekes megfigyelni, hogy itt már bekerült az első hat mezőnyébe a szigorú, ami egyértelmúen arra utal, hogy valamiért a szakgimnáziumi tanulók elvárják a jó pedagógustól a szigort, vagyis a korlátozást is. Itt 
nyilván felsejlik bennem a gondolat, talán nem véletlen az összefüggés a kapott eredményekkel, vagyis hogy kissé elhanyagolónak érzékelik tanáraikat, tehát elvárnának egy kis szigort is, míg a szakközépiskolások tekintélyelvúnek (hideg-korlátozó) érzékelik őket, így inkább engedékenységet várnának. Szakgimnáziumban is nagy többségben szerepelnek egyébként az elfogadó tanár tulajdonságai, mint például türelmes, kedves, megértő, közvetlen, barátságos, nyitott, őszinte... stb., míg a korlátozás mértékére utaló leggyakoribb tulajdonságok: szigorú, határozott, kemény... stb. A szakgimnáziumi tanulók által a három legfontosabb tulajdonság a kedvesség, a segítókészség és a szigor, tehát őket talán a melegebb, némileg korlátozóbb pedagógus motiválná (14. ábra). Véleményem szerint ennek a vizsgálatnak az eredményei abba az irányba mutatnak, hogy a tanulók többségét az elfogadó (meleg) tanár motiválja leginkább, a korlátozás mértéke azonban változó, attól függően milyen iskolatípusba jár, vagy otthon milyen nevelői attitűdökkel találkozott.

\section{4. ábra: A szakgimnáziumi tanulók által legfontosabbnak ítélt személyiségfejlődést segítő pedagógusi tulajdonságok}

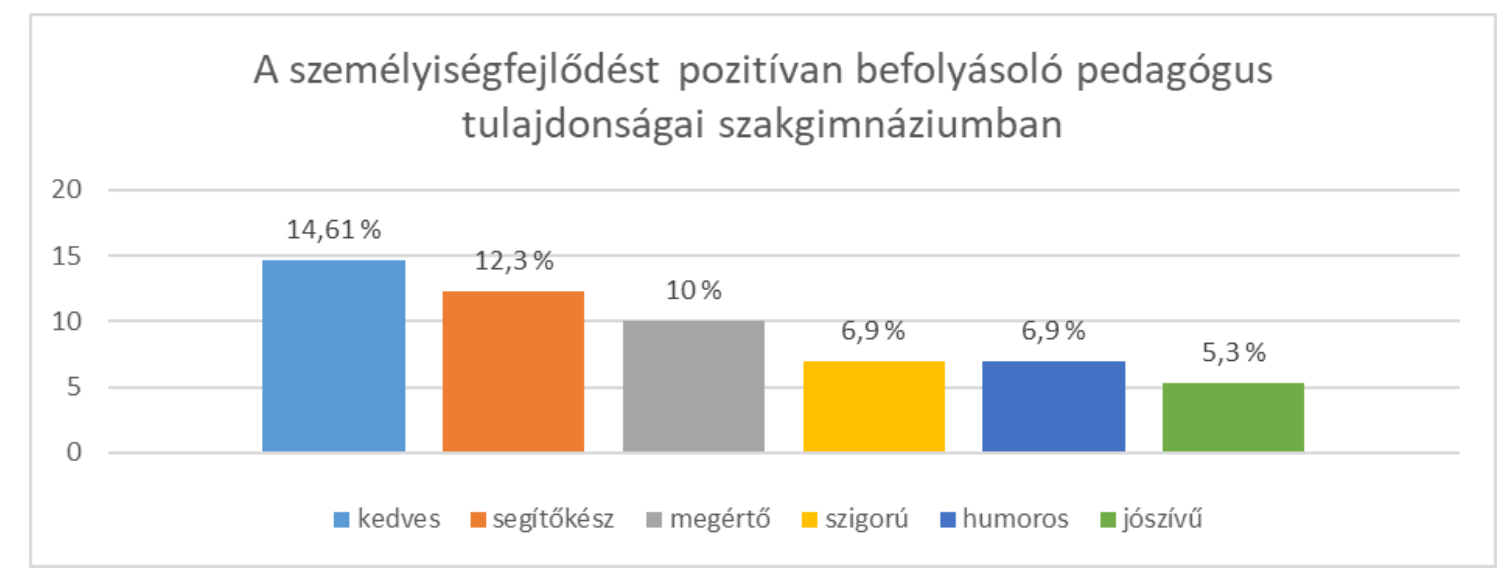

\section{Összegzés}

Mivel olyan vizsgálati módszereket választottam, melyek során kérdőívek segítségével a tanulók egyszemélyben nyilatkoznak önmagukról, szüleikről és az őket tanító tanárokról, így a vizsgálati eredményeket is annak tudatában érdemes kiértékelni, hogy a szülői és a pedagógusi attitúdöket vizsgáló kérdőívek nem a szülők és a pedagógusok tényleges attitúdjét mérik, hanem azt, hogy a tanulók milyennek érzékelik azokat. Az önértékelési kérdőívek többé-kevésbé a várt eredményeket hozták, mindkét csoport (szakközépiskolai és szakgimnáziumi) esetében az átlaghoz közeli eredmények születtek. Ha az önérték-indexek alacsonyak, az alskálák egyértelműen megmutatják, hogy az adott tanuló alacsony önértékelését életének mely szegmense okozza: a társas kapcsolatok vagy az otthoni kapcsolatok problémái, esetleg az iskolai eredménytelenség. Több tanuló esetében is megfigyelhető, hogy az otthon alskála alacsony értéket kapott, majd később a szülői attitűdöket mérő kérdőív igazolta, hogy a tanuló úgy érzékeli, hogy valamelyik vagy mindkét szülő elutasító vele szemben. A vizsgálat során kiderült, hogy a szülők nagyrésze meleg-engedékeny, mely szintén nem lepett meg, hiszen jelenleg Magyarországon ez a szülőtípus a leggyakoribb, nyilván ennek kulturális okai vannak. Ha a két kérdőívet összeegyeztetjük, általánosságban megfigyelhető, hogy a legalacsonyabb önérték-indexszel rendelkező tanulók szülei inkább elutasítók (hidegek), itt a korlátozás mértéke változó, a legmagasabb önérték-indexszel rendelkező tanulók szülei viszont meleg-engedékenyek. Érdemes megemlíteni, hogy a szülői elfogadás nem minden esetben elegendő a reális, egészséges önértékeléshez, szükséges a társak elfogadása és az iskolai eredményesség is. A pedagógusok esetében rendkívül szerteágazó 
véleményeket kaptam, ezért igen nehéz volt kiértékelni és valamiféle törvényszerűséget megfigyelni, én mégis megpróbálkoztam ezzel. Arra jutottam, hogy a szakközépiskolai tanulók kissé elutasítónak és korlátozónak (tekintélyelvűnek) érzékelik tanáraikat, míg a szakgimnáziumi tanulók szintén elutasítónak, de engedékenynek (elhanyagolónak). Ha a tanulók önérték-indexe felól közelítem meg a pedagógusok attitűdjét, itt szintén kiderül, hogy az önértékelést leginkább pozitív irányba befolyásoló pedagógus elfogadó és engedékeny. Ezt támasztja alá a tanulók szöveges értékelése is, miszerint a legösztönzőbb pedagógus kedves, segítőkész, barátságos, figyelmes, megértő. A szakgimnáziumi tanulók egy kis szigort is szívesen fogadnak, ez ebben az iskolatípusban (főleg a vizsgálat eredményének fényében) nem meglepő. Vizsgálatom tehát rámutatott, hogy a fejlődő lélek számára a legfontosabb a szeretet és az elfogadás, mind a szülő, mind a pedagógus részéről, hiszen a szülői és a pedagógusi melegség hatására magasabb a tanulók önérték-indexe, az elutasító szülői vagy pedagógusi magatartás mellett azonban alacsonyabb. Általánosságban elmondható, hogy a korlátozás mértéke kevésbé befolyásoló tényező.

Nevelni (legyen az akár szülő, akár pedagógus) csak türelemmel, odafigyeléssel, szeretettel lehet. A legrosszabb, amit egy fejlődő lélekkel tehetünk, ha érzelmileg elutasítjuk, elhanyagoljuk, illetve ha túlkorlátozzuk, mert ezzel csüggedtté, kishitúvé, szorongóvá, bizalmatlanná tesszük a világgal és önmagával szemben is. Ha sikeres gyermekeket szeretnénk adni a világnak, akkor sikerre kell nevelni őket, érzelmi stabilitást és fizikai biztonságot kell nyújtani számukra. Fel kell készíteni őket az élet kihívásaira, engednünk kell hibázni őket, meg kell tanítanunk őket gondolkodni, önállóan dönteni, segítenünk kell nekik megismerni önmagukat, a képességeiket és a hiányosságaikat egyaránt. Meg kell tanítanunk nekik, hogy ők mindannyian értékes tagjai a világnak függetlenül attól, hogy hova, milyen körülmények közé születtek, mekkora az intelligencia-hányadosuk, ugyanis a mai világban már sokkal fontosabb az érzelmi intelligencia, az érzelmi stabilitás és a reális énkép, mert ezek segítségével lesznek képesek beilleszkedni a társadalomba illetve talpra állni az egyes kudarcélmények után... De mindez csak akkor lehetséges, ha elfogadó környezetben, otthon és az iskolában is megértő és szeretetteljes odafigyelésben nevelkednek.

\section{Felhasznált szakirodalom}

- Pszichológiai alapfogalmak kis enciklopédiája, Tankönyvkiadó, Budapest, 1987

- Csepeli György, Szociálpszichológia, Osiris Kiadó, Budapest, 2001

- Rita L. Atkinson - Richard C. Atkinson - Edward E. Smith - Daryl J. Bem - Susan NolenHoeksema, Pszichológia, Osiris Kiadó, Budapest, 1999

- Dr. Bagdy Emőke, Családi szocializáció és személyiségzavarok, Tankönyvkiadó, Budapest, 1986

- Dr. Buda Béla, A személyiségfejlődés és a nevelés szociálpszichológiája, Tankönyvkiadó, Budapest, 1986

- Thomas Gordon, P. E. T. A szülői eredményesség tanulása, Gordon Könyvek, 1999

- Michael Cole - Sheila R. Cole, Fejlödéslélektan, Osiris Kiadó, Budapest, 2003

- Dr. Ranschburg Jenő, Félelem, harag, agresszió, Tankönyvkiadó, Budapest, 1979

- Pléh Csaba, Hagyomány és újitás a pszichológiában, Balassi Kiadó, Budapest, 1998

- Gordon W. Allport, A személyiség alakulása, Gondolat, Budapest, 1985

- Ranschburg Jenő, Családi kör, RTV-Minerva, Budapest, 1997

- Thomas Gordon, T. E. T. A tanári hatékonyság fejlesztése, Gordon Könyvek, 1999

- Együttérzés, önzetlenség, felelősség, Tankönyvkiadó, Budapest, 1983

- Pszichológia, Az MTA Pszichológiai intézetének folyóirata, 1984/4 
- Mérlegen a magyar iskola, szerk. Csapó Benő, Nemzeti Tankönyvkiadó, 2012

- Nagy Judit, A szülöi-nevelői attitüd és a gyermek önértékelésének összefüggése, Berzsenyi Dániel Főiskola, Testnevelési és Múvészeti Főiskolai Kar, Szombathely, 2003

- Báthory Zoltán - Falus Iván: Pedagógiai lexikon III., Keraban, Budapest, 1997

- Sipos Imre, A közoktatási intézmény hatékonysága, Budapesti Múszaki és Gazdaságtudományi Egyetem, Budapest, 2013

- Dr. Hegyi Ildikó, Siker és kudarc a pedagógus munkájában, Okker Oktatási Iroda, Budapest,1996

- Az attitüd pszichológiai kutatásának kérdései, szerk.: Halász László, Hunyadi György, Marton L. Magda. Akadémia Könyvkiadó, Budapest, 1979

- Zétényi Ágnes, A hatékony tanár, in. Iskolakultúra, 1997/10.

- Pőcze Gábor, A pedagógus szakmához tartozó képességek, Okker Oktatási Iroda, Budapest, 1996

\section{Internetes hivatkozások}

- http://epa.oszk.hu/02400/02401/00041/pdf/EPA02401 Hungarologiai kozlemenyek 2011 04 075-088.pdf

- https://www.tankonyvtar.hu/hu/tartalom/tamop412A/2009 0026 kovi szocialpsziho/2162 az attitdk s nzetrendszerek mint az egynre jellemz gondolkodsi stlus sszetevi.html

- https://www.tankonyvtar.hu/hu/tartalom/tamop425/2011 0001520 neveleslelektan/ch02 s02.html

- $\quad$ http://rmpsz.ro/uploaded/tiny/files/magiszter/2003/tel/4.pdf

- $\quad$ http://xrvpzdx.edia.hu/mped/document/Sallay MP1033.pdf

- http://epa.oszk.hu/00000/00011/00059/pdf/iskolakultura EPA00011 200204 107-114.pdf

- https://sites.google.com/site/kisseszter123/tanari-attitudoek

- http://magyarpedagogia.hu/document/2 133 Sallay\%20Hedvig.pdf

- http://www.ppk.elte.hu/file/fuzi beatrix dissz.pdf

- http://rpi.reformatus.hu/sites/default/files/hir kepek/PPI.pdf

- http://www.jgypk.hu/mentorhalo/tananyag/Tanulk s tanulcsoportok megismerse kiemelt figyelmet ignyl tanulk/nrtkels.html

- http://mek.oszk.hu/04600/04669/html/balogh pedpszich0044/balogh pedpszich0044.html

- http://acta.bibl.u-szeged.hu/30459/1/sana 2012002 042-043.pdf

- http://real-j.mtak.hu/4951/1/Pszichologia 04.pdf

- http://real.mtak.hu/63628/1/EPA00011 iskolakultura 200204 7.pdf

- https://www.citatum.hu/szerzo/Csikszentmihalyi Mihaly

- https://hu.wikipedia.org/wiki/\%C3\%96n\%C3\%A9rt\%C3\%A9kel\%C3\%A9s

- https://derep-k.drhe.hu/39/2/Pszichologiai-vizsgalati-modszerek-gyujtemenye-javitottkiadas2017-nyomda-20170830.pdf

- https://hu.wikipedia.org/wiki/\%C3\%89rzelmi intelligencia

- https://mindsetpszichologia.hu/2017/11/29/mi-is-az-az-eq-es-hogyan-fejleszthetjuk/

- http://eduline.hu/segedanyagtalalatok/letolt/5671 


\section{1. sz. melléklet}

\section{A SEl magyar átlagai és szórásai}

nemek és alskálák szerinti bontásban

$\begin{array}{lllllll}\text { S (self) } & 36,44 & 9,33 & 38,57 & 9,19 & 37,59 & 9,33 \\ \text { I (iskola) } & 9,25 & 4,26 & 9,96 & 3,74 & 9,69 & 4,50 \\ \text { O (otthon) } & 12,67 & 3,60 & 13,71 & 2,89 & 13,27 & 3,79 \\ \text { T (társak) } & 11,33 & 5,28 & 11,83 & 3,25 & 11,66 & 4,78 \\ \text { Önérték-index } & 69,68 & 17,31 & 74,06 & 15,26 & 72,21 & 18,08\end{array}$

Érdekes, ha átszámítjuk a „self” adatokat, hogy a többivel azonos számú itemből álló alskálának feleljen meg. Így közvetlenül szemlélhetjük, hogy a négy tényező milyen arányban vesz részt az önérték index kialakulásában. Self: 11,7; iskola: 9,7; otthon: 13,3; társak: 11,7. Vagyis legerősebb az otthon hozzájárulása, százalékra átszámítva 28,7\%; utána teljesen egyforma a self és a társak adata: 25,2-25,2; végül az iskola következik 20,9\%-kal.

\section{2. sz. melléklet}

\begin{tabular}{|c|c|c|c|c|}
\hline & \multicolumn{4}{|c|}{ Átlag pontértékek } \\
\hline & \multicolumn{2}{|c|}{ Apa } & \multicolumn{2}{|c|}{ Anya } \\
\hline & fiú & lány & fiú & lány \\
\hline Meleg-hideg & 6,6 & 6,8 & 7,4 & 7,5 \\
\hline Engedékeny-korlátozó & 6,3 & 6,4 & 5,7 & 6,2 \\
\hline
\end{tabular}




\section{3. sz. melléklet}

\section{A PEDAGÓGUSI ATTITÚD VIZSGÁLATA}

(Likert-skála)

Név:

Olvasd el figyelmesen az egyes állításokat, azután döntsd el, hogy az adott állítás a téged tanító tanárokra (egészen az 1. osztálytól kezdve mostanáig) általánosságban mennyire igaz: nem igaz - ritkán igaz - gyakran igaz - igaz, majd válaszod jelöld X-szel a megfelelő oszlopban!

\begin{tabular}{|c|c|c|c|c|c|}
\hline & I. & $\begin{array}{l}\text { nem } \\
\text { igaz }\end{array}$ & $\begin{array}{c}\text { ritkán } \\
\text { igaz }\end{array}$ & $\begin{array}{l}\text { gyakran } \\
\text { igaz }\end{array}$ & igaz \\
\hline 1. & A tanárok szívesen beszélgetnek velem. & & & & \\
\hline 2. & A tanárok megértőek velem szemben. & & & & \\
\hline 3. & A tanárok figyelembe veszik az érdekeimet. & & & & \\
\hline 4. & $\begin{array}{l}\text { A tanárok szívesen elmagyaráznak mindent, amit } \\
\text { nem értek. }\end{array}$ & & & & \\
\hline 5. & $\begin{array}{l}\text { A tanároktól mindig kérdezhetek, mindig szóba } \\
\text { állnak velem. }\end{array}$ & & & & \\
\hline 6. & $\begin{array}{l}\text { A tanárok érdeklődnek a lelkiállapotom, hogylétem } \\
\text { felől. }\end{array}$ & & & & \\
\hline 7. & $\begin{array}{l}\text { A tanárok együttmúködnek szüleimmel, hogy } \\
\text { jobban teljesítsek. }\end{array}$ & & & & \\
\hline 8. & A tanárok segítenek nekem, ha bajban vagyok. & & & & \\
\hline 9. & A tanárok észreveszik, ha gondjaim vannak. & & & & \\
\hline 10. & A tanárok szeretnek és elfogadnak engem. & & & & \\
\hline 11. & $\begin{array}{l}\text { A tanárok figyelembe veszik a lelkiállapotomat a } \\
\text { teljesítményem értékelése során. }\end{array}$ & & & & \\
\hline 12. & $\begin{array}{l}\text { A tanárok őszintén örülnek, megdicsérnek, ha javul } \\
\text { a teljesítményem }\end{array}$ & & & & \\
\hline
\end{tabular}




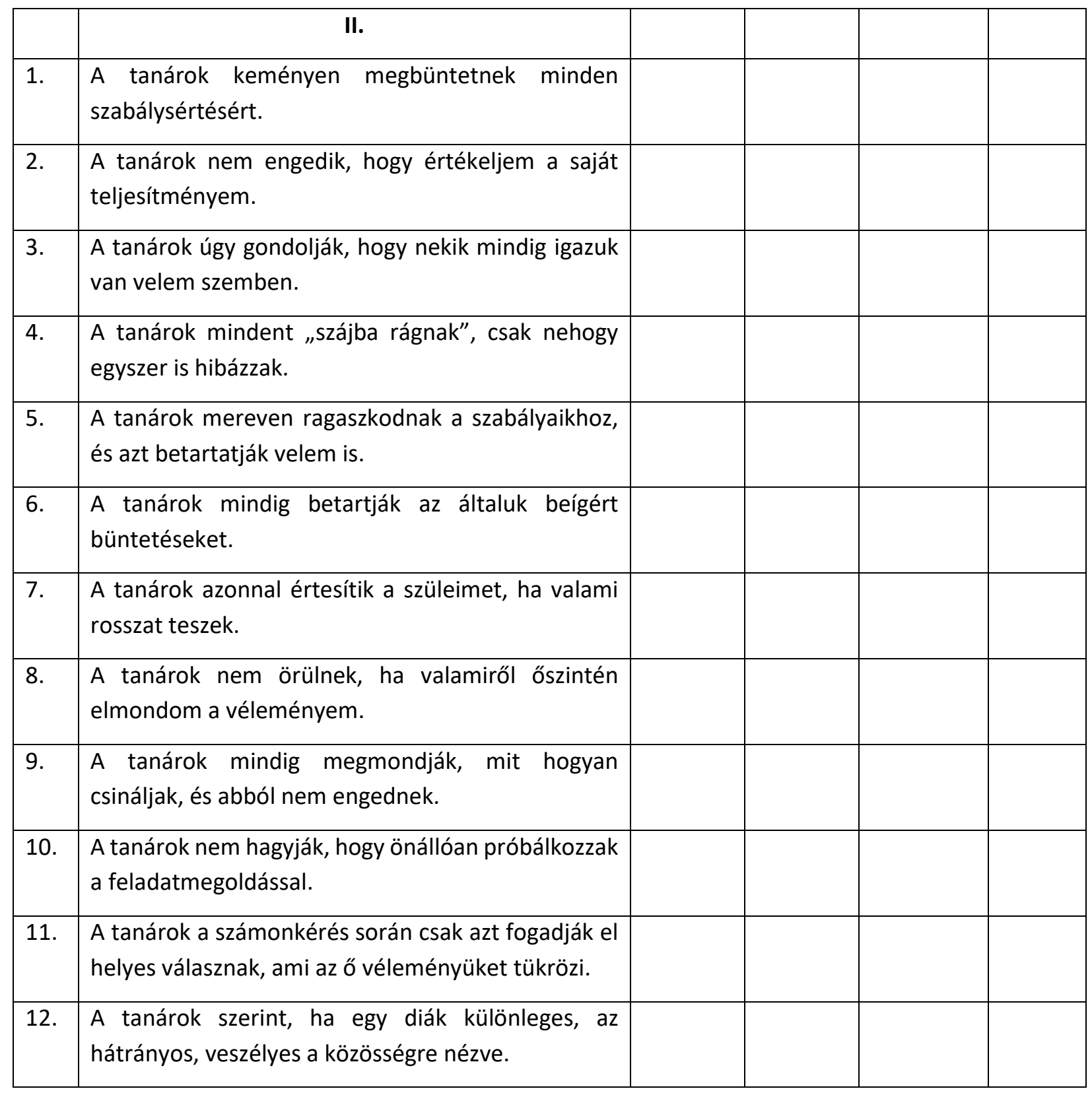

Véleményed szerint milyen tulajdonságokkal rendelkezik az a tanár, aki pozitívan befolyásolja személyiségedet, hozzájárul lelki-szellemi fejlődésedhez! Nevezz meg 5 tulajdonságot fontossági sorrendben! Kezdd a legfontosabbal!

1.

2.

3.

4.

5. 


\begin{tabular}{|l|l|l|l|l|l|}
\hline \multicolumn{2}{|l|}{ I. A pedagógus emocionális viselkedése } & \multicolumn{3}{|l|}{ II. A korlátozás mértéke } \\
\hline nem igaz & hideg & 0 pont & nem igaz & engedékeny & 3 pont \\
\hline ritkán igaz & inkább hideg & 1 pont & ritkán igaz & inkább engedékeny & 2 pont \\
\hline gyakran igaz & inkább meleg & 2 pont & gyakran igaz & inkább korlátozó & 1 pont \\
\hline igaz & meleg & 3 pont & igaz & korlátozó & 0 pont \\
\hline
\end{tabular}

